\title{
How to facilitate cannulation of an intradiverticular papilla: a technique with two devices in one channel using pediatric forceps
}

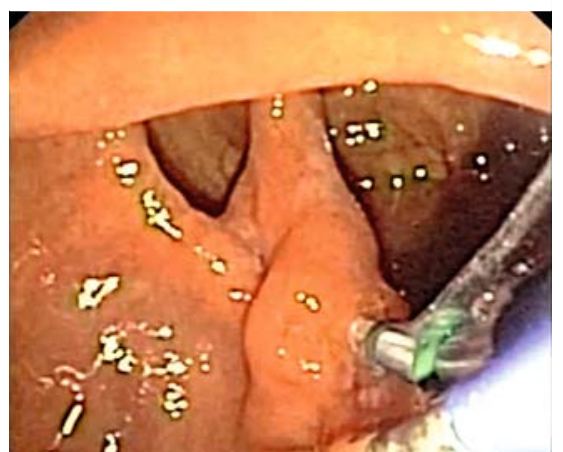

- Fig. 1 Endoscopic view showing the two devices coming out of the operating channel immediately after cannulation and bile duct catheterization.

The proportion of patients undergoing endoscopic retrograde cholangiopancreatography (ERCP) with a periampullary duodenal diverticulum ranges in the literature from $9 \%$ to $32 \%$ [1]. The prevalence of periampullary diverticula increases with age, and they are associated with a higher risk of choledocholithiasis [2]. In a few series, they have been identified as a risk factor for difficulty in and failure of biliary catheterization [3]. Several techniques have been proposed to facilitate cannulation, such as clips, or in one case forceps [4,5]. - Video 1 shows three patients who benefited from our technique involving double instrumentation in one channel for the treatment of biliary obstruction with peridiverticular papillae.

Among 7151 ERCPs performed between 2008 and 2017, a duodenal diverticulum was found in 346 patients (5\%). Among these, nine patients with a non-visible or non-reachable orifice benefited from the previously described technique for cannulation. The objective was to reverse the papilla's orifice to stabilize it in front of the sphincterotome.

The procedures were performed with a duodenoscope (Olympus TJF 160; oper-

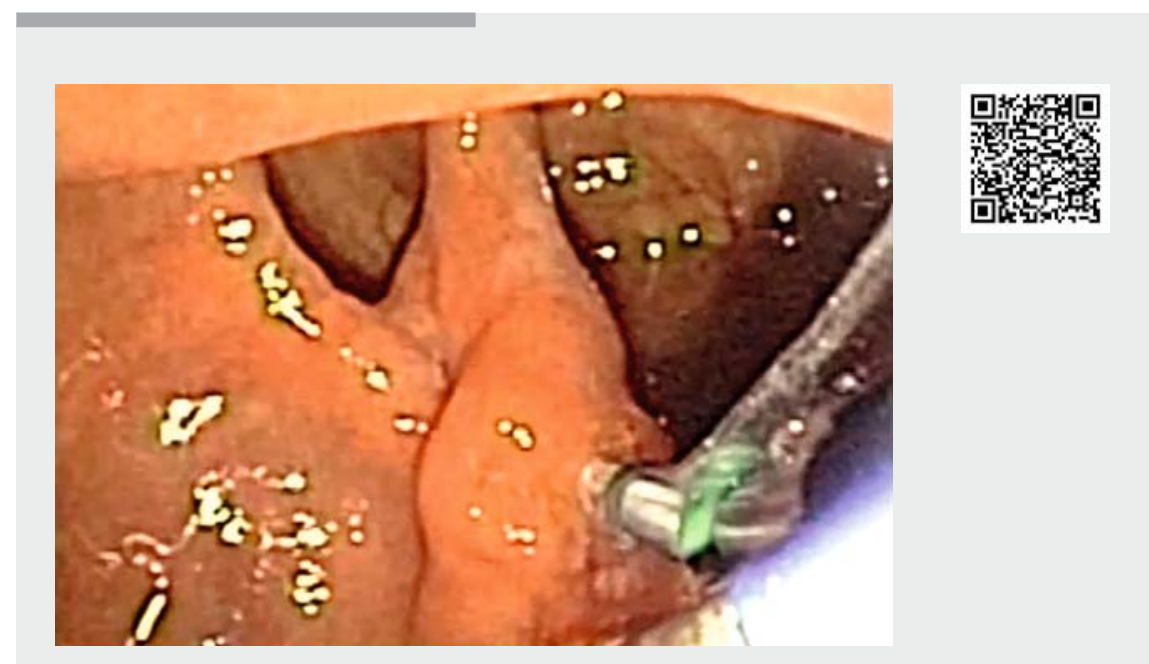

Video 1 Video showing three patients with intradiverticular papillae who underwent cannulation for endoscopic retrograde cholangiopancreatography using the two devices simultaneously inserted in one channel.

ating channel $4.2 \mathrm{~mm}$ ). The devices used were a sphincterotome (Cotton Cannulatome II; Cook Medical, USA) loaded with a 0.035-inch guidewire (JagWire; Boston Scientific, USA) and pediatric biopsy forceps (Captura $1.8 \mathrm{~mm}$; Cook Medical), which were simultaneously introduced into the operating channel. The papilla was grasped at its base and pulled back towards the tip of the sphincterotome, which was advanced to catheterize the bile duct with the wire ( $\mathbf{F i g} . \mathbf{1}$ ). The procedure was successful in less than 10 minutes without the need for a precut in all of the patients. The findings were biliary stones in six patients, undetermined stricture in two patients, and pancreatic cancer in one patient. No adverse events occurred.

In conclusion, this approach using pediatric forceps simultaneously introduced with the sphincterotome to fix the papilla and facilitate cannulation is very useful, safe, and effective in patients with a periampullary diverticulum and difficult access to the orifice, helping to avoid the need for a challenging precut.

Endoscopy_UCTN_Code_TTT_1AR_2AC

Competing interests

None

The authors

Jean-Michel Gonzalez, Antoine Debourdeau, Marc Barthet

Department of Digestive Endoscopy, AixMarseille Université, AP-HM, Hôpital Nord, Marseille, France 


\section{Corresponding author}

\section{Jean-Michel Gonzalez, MD}

Department of Digestive Endoscopy,

AP-HM, Hôpital Nord, Chemin des Bourrelys,

13015, Marseille, France

jean-michel.gonzalez@ap-hm.fr

\section{References}

[1] Tyagi P, Sharma P, Sharma BC et al. Periampullary diverticula and technical success of endoscopic retrograde cholangiopancreatography. Surg Endosc Other Interv Tech 2009; 23: $1342-1345$

[2] Kim CW, Chang JH, Kim JH et al. Size and type of periampullary duodenal diverticula are associated with bile duct diameter and recurrence of bile duct stones. J Gastroenterol Hepatol 2013; 28: $893-898$
[3] Zoepf T, Zoepf DS, Arnold JC et al. The relationship between juxtapapillary duodenal diverticula and disorders of the biliopancreatic system: Analysis of 350 patients. Gastrointest Endosc 2001; 54: 56-61

[4] Altonbary AY, Bahgat MH. Endoscopic retrograde cholangiopancreatography in periampullary diverticulum: The challenge of cannulation. World J Gastrointest Endosc 2016; 8: 282

[5] Fujita N, Noda Y, Kobayashi G et al. ERCP for intradiverticular papilla: Two-devices-inone-channel method. Gastrointest Endosc 1998; 48: $517-520$

\section{Bibliography}

DOI https://doi.org/10.1055/a-0919-4154

Published online: 4.6.2019

Endoscopy 2019; 51: 1095-1096

(c) Georg Thieme Verlag KG

Stuttgart · New York

ISSN 0013-726X
ENDOSCOPY E-VIDEOS

https://eref.thieme.de/e-videos

口回 Endoscopy E-Videos is a free access online section, reporting 田: on interesting cases and new techniques in gastroenterological endoscopy. All papers include a high quality video and all contributions are freely accessible online.

This section has its own submission website at

https://mc.manuscriptcentral.com/e-videos 